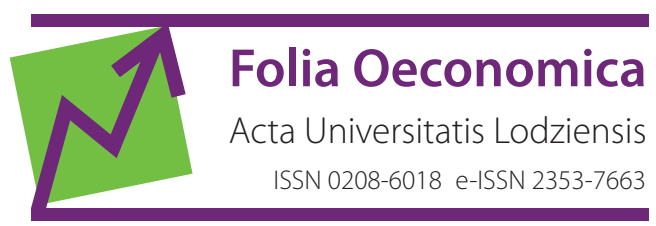

www.czasopisma.uni.lodz.pl/foe/

2(347) 2020

DOI: http://dx.doi.org/10.18778/0208-6018.347.01

\author{
Radosław Murkowski \\ Uniwersytet Ekonomiczny w Poznaniu, Wydział Ekonomii \\ Katedra Polityki Gospodarczej i Samorządowej \\ radoslaw.murkowski@ue.poznan.pl
}

\title{
Stan i perspektywy procesu starzenia się ludności na świecie
}

Streszczenie: Starzenie się ludności oznacza proces wzrostu odsetka osób starszych w populacji, który jest efektem dwóch długoterminowych trendów demograficznych - zmniejszania się płodności i zwiększania się przeciętnej długości życia. Dla prawidłowego pomiaru zaawansowania tego procesu niezmiernie istotne jest to, jaki wiek uznamy za początek starości. W ujęciu tradycyjnym za osoby starsze uznaje się najczęściej osoby w wieku 60 lub 65 lat i więcej. Natomiast w alternatywnym ujęciu za początek okresu starości można uznać na przykład wiek, dla którego oczekiwane dalsze trwanie życia wynosi dokładnie 15 lat. W wielu miejscach na świecie nieuchronnie wystąpi w przyszłości zjawisko depopulacji, a liczba dzieci stanie się niższa od liczby osób starszych. Osoby w wieku 60 lat i więcej będą w przyszłości stanowić w wielu regionach blisko jedną trzecią ludności. Natomiast odsetek osób, którym zostało mniej niż 15 lat życia, w krajach najbardziej rozwiniętych ustabilizuje się w przyszłości na poziomie około 15\% ich populacji. Dlatego granica określająca początek okresu starości w ujęciu tradycyjnym będzie się w przyszłości zwiększać nawet do 70 lat i więcej w państwach najbardziej rozwiniętych.

Słowa kluczowe: starzenie się populacji, alternatywne miary starzenia się populacji, prognozy demograficzne, starość, początek okresu starości

JEL: J11, J14, J13 


\section{Wprowadzenie}

W świetle teorii przejścia demograficznego rozwój liczby ludności następuje w sposób fazowy - od wysokiego poziomu urodzeń i zgonów, przez fazę charakteryzującą się eksplozją demograficzną, aż do momentu, w którym zarówno zgony, jak i urodzenia stabilizują się na niskim poziomie. Współczesne modyfikacje tej koncepcji wskazują na pojawienie się fazy, w której - w zależności od przyjętych założeń - może nastąpić spadek przyrostu naturalnego poniżej poziomu zastępowalności pokoleń albo jego ponowny wzrost (Myrskylä, Kohler, Billari, 2009). Ogólnie rzecz biorąc, rozwój ludności w ostatnich dziesięcioleciach potwierdza podstawowe założenia tej teorii. W ciągu ostatnich dwóch stuleci obserwowano na świecie najpierw globalny wzrost ludności, zwany eksplozją demograficzną, a następnie spadek dzietności oraz zjawisko starzenia się światowej populacji. Dlatego dzisiejsza debata demograficzna w mniejszym stopniu skupia się na zagrożeniu przeludnieniem świata, a w większym dotyka tematów związanych ze starzeniem się ludności czy możliwością wystąpienia zjawiska depopulacji.

Starzenie się ludności to proces wzrostu odsetka osób starszych w populacji, który jest efektem dwóch długoterminowych trendów demograficznych - zmniejszania się płodności i zwiększania się średniej długości życia. Długowieczność jest wynikiem postępu w procesie rozwoju człowieka, spowodowanego między innymi poprawą w zakresie odżywiania, warunków sanitarnych czy opieki zdrowotnej oraz pojawiania się innowacji przemysłowych, medycznych i technologicznych. Proces starzenia się ludności ma obecnie zasięg globalny i dotyczy już praktycznie wszystkich regionów świata, choć na różnych kontynentach przebiega jeszcze z odmienną intensywnością. Dla prawidłowego pomiaru zaawansowania tego procesu niezmiernie istotne jest to, jaki wiek uznamy za początek okresu starości. Przyjęcie takiego samego progu starości dla państw będących na różnym poziomie rozwoju społeczno-gospodarczego może budzić uzasadnione kontrowersje. Ponadto ważny jest nie tylko sam fakt dożycia określonego wieku, lecz także to, ile lat po jego osiągnięciu się przeżyje.

W ujęciu tradycyjnym za osoby starsze uznaje się zazwyczaj te, które osiągnęły wiek 60 lub 65 lat. W tym przypadku pomiar procesu zaawansowania starzenia ludności odbywa się najczęściej przez określenie odsetka osób starszych w całej populacji czy też za pomocą wskaźników określających relację między osobami starszymi i młodymi (wskaźniki starości) lub między osobami w wieku produkcyjnym a osobami w wieku nieprodukcyjnym (współczynniki obciążenia demograficznego). Tradycyjny pomiar starzenia się ludności uznaje osobę za starą po przeżyciu przez nią określonej liczby lat, niezależnie od jej stanu zdrowia, dlatego jest to ujęcie niewystarczające do adekwatnego pomiaru zaawansowania tego procesu. Ludność poszczególnych populacji różni się zasadniczo przeciętną długością życia czy ogólnym stanem zdrowia, dlatego starzeje się średnio w róż- 
nym wieku. Skoro jedne populacje starzeją się średnio szybciej, a inne wolniej, powinno mieć to wpływ na właściwy pomiar zaawansowania tego zjawiska.

Alternatywne ujęcie starzenia się ludności zakłada, że moment uznania danej osoby za starą jest różny dla poszczególnych populacji i jednocześnie zmienia się w czasie - między innymi w zależności od wydłużania się ludzkiego życia skorelowanego z poprawą stanu zdrowia ludności (Abramowska-Kmon, 2011). W niniejszym artykule wykorzystano zaproponowane przez europejskich badaczy (Sanderson, Scherbov, 2005a; 2005b; 2008; 2010; Lutz, Sanderson, Scherbov, 2008) miary służące do oceny stopnia zaawansowania procesu starzenia się ludności, uznające za początek okresu starości wiek, dla którego oczekiwane dalsze trwanie życia wynosi dokładnie 15 lat. Wraz z poprawą stanu zdrowia ludności wydłuża się średnia długość życia, a w konsekwencji opóźnia się moment wystąpienia znamion określających początek okresu starości. W takim ujęciu pomiar zaawansowania starzenia się ludności określa się między innymi na podstawie kalkulacji proporcji osób, dla których oczekiwane dalsze trwanie życia wynosi 15 lat i mniej wśród ogółu ludności. Dlatego zasadniczym celem analizy jest ocena stopnia zaawansowania i perspektyw starzenia się ludności świata przy użyciu nie tylko powszechnie stosowanych miar tradycyjnych, ale również alternatywnych (zob. Murkowski, 2018). Podstawowym źródłem danych wykorzystanym w opracowaniu była rewizja prognozy ludności świata z 2017 roku, sporządzona przez ekspertów ONZ (United Nations, 2017).

\section{Zaawansowanie procesu starzenia się ludności świata}

Przez ostatnie dwieście lat na świecie notowano zjawisko wzrostu zaludnienia, zwane eksplozją demograficzną. Szacuje się, że liczba ludności świata osiągnęła miliard w 1804 roku, dwa miliardy dopiero 123 lata później, tj. w 1927 roku, a kolejne 33 lata zajęło ludzkości przekroczenie trzech miliardów. Globalna populacja osiągnęła cztery miliardy w 1974 roku, pięć miliardów w 1987 roku, sześć miliardów w 1999 roku, a dziś wynosi już ponad siedem miliardów. Według najnowszej projekcji ludności sporządzonej przez ONZ w jej najbardziej prawdopodobnym wariancie (wariant średniej płodności) liczba ludności świata między 2020 a 2025 rokiem wyniesie osiem miliardów osób, około 2055 roku przekroczy dziesięć miliardów, a pod koniec stulecia ustabilizuje się na poziomie około jedenastu miliardów (zob. Tabela 1). Jednocześnie tempo wzrostu zaludnienia świata będzie cały czas się zmniejszać i już po 2020 roku spadnie poniżej 1\% rocznie, a pod koniec wieku będzie się kształtować na poziomie nieznacznie wyższym od zera. W scenariuszu tym przewiduje się, że współczynnik dzietności całkowi- 
tej na świecie spadnie około 2075 roku poniżej poziomu gwarantującego zastępowalność pokoleń. Projekcja ONZ zakłada jednocześnie, że oczekiwane przeciętne dalsze trwanie życia noworodka będzie się systematycznie zwiększać, osiągając pod koniec wieku wielkość około 80 lat dla mężczyzn oraz blisko 85 lat dla kobiet.

Tabela 1. Projekcje ludności świata (dane w mln)

\begin{tabular}{|l|r|r|r|r|r|r|r|r|}
\hline \multicolumn{1}{|c|}{ Wyszczególnienie } & $\mathbf{1 9 5 0}$ & $\mathbf{2 0 0 0}$ & $\mathbf{2 0 1 5}$ & $\mathbf{2 0 3 0}$ & $\mathbf{2 0 5 0}$ & $\mathbf{2 0 8 0}$ & $\mathbf{2 1 0 0}$ \\
\hline \multicolumn{2}{|c|}{ Wariant średniej plodności } \\
\hline Ludność ogółem & 2536 & 6145 & 7383 & 8551 & 9772 & 10849 & 11184 \\
\hline Ludność w wieku 0-19 lat & 1108 & 2420 & 2524 & 2686 & 2759 & 2747 & 2648 \\
\hline Ludność w wieku 20-59 lat & 1226 & 3113 & 3953 & 4459 & 4933 & 5328 & 5395 \\
\hline Ludność w wieku 60 lat i więcej & 202 & 612 & 906 & 1406 & 2081 & 2773 & 3141 \\
\hline Ludność w wieku 65 lat i więcej & 129 & 423 & 612 & 997 & 1546 & 2175 & 2515 \\
\hline Ludność w wieku 80 lat i więcej & 14 & 72 & 126 & 202 & 425 & 723 & 909 \\
\hline Ludność, której zostało 15 lat życia i mniej & 229 & 417 & 502 & 724 & 1044 & 1337 & 1498 \\
\hline \multicolumn{7}{|c|}{ Wariant wysokiej plodności } \\
\hline Ludność ogółem & 2536 & 6145 & 7383 & 8875 & 10849 & 14088 & 16521 \\
\hline Ludność w wieku 0-19 lat & 1108 & 2420 & 2524 & 3011 & 3516 & 4341 & 4864 \\
\hline Ludność w wieku 20-59 lat & 1226 & 3113 & 3953 & 4459 & 5253 & 6911 & 7991 \\
\hline Ludność w wieku 60 lat i więcej & 202 & 612 & 906 & 1406 & 2081 & 2836 & 3666 \\
\hline Ludność w wieku 65 lat i więcej & 129 & 423 & 612 & 997 & 1546 & 2175 & 2889 \\
\hline Ludność w wieku 80 lat i więcej & 14 & 72 & 126 & 202 & 425 & 723 & 952 \\
\hline Ludność, której zostało 15 lat życia i mniej & 229 & 417 & 502 & 725 & 1044 & 1337 & 1648 \\
\hline \multicolumn{7}{|c|}{ Wariant niskiej płodności } \\
\hline Ludność ogółem & 2536 & 6145 & 7383 & 8227 & 8753 & 8209 & 7276 \\
\hline Ludność w wieku 0-19 lat & 1108 & 2420 & 2524 & 2362 & 2060 & 1581 & 1267 \\
\hline Ludność w wieku 20-59 lat & 1226 & 3113 & 3953 & 4459 & 4613 & 3917 & 3387 \\
\hline Ludność w wieku 60 lat i więcej & 202 & 612 & 906 & 1406 & 2081 & 2711 & 2621 \\
\hline Ludność w wieku 65 lat i więcej & 129 & 423 & 612 & 997 & 1546 & 2175 & 2143 \\
\hline Ludność w wieku 80 lat i więcej & 14 & 72 & 126 & 202 & 425 & 723 & 867 \\
\hline Ludność, której zostało 15 lat życia i mniej & 229 & 417 & 502 & 725 & 1044 & 1337 & 1347 \\
\hline
\end{tabular}

Źródło: opracowanie własne na podstawie projekcji ONZ (dane rzeczywiste do 2015 roku)

Scenariusz rozwoju ludności świata w wariancie średniej płodności zakłada, że w niedalekiej przyszłości nastąpi zasadnicza zmiana struktury ludności świata według wieku. Po pierwsze, przewiduje się, że około 2080 roku liczba osób w wieku 60 lat i więcej stanie się po raz pierwszy w historii większa niż liczba osób w wieku 20 lat i mniej (zob. Rysunek 1). Ponadto odsetek osób młodych może pod koniec wieku stanowić niewiele ponad $20 \%$ ogółu ludności świata - dla porównania jeszcze na początku lat siedemdziesiątych XX wieku była to prawie połowa ludności świata. Po drugie, liczba osób w wieku produkcyjnym będzie w przyszłości rosła coraz wolniej, a w wielu państwach na świecie zacznie się nawet zmniejszać. Obecnie liczba osób w wieku 20-59 lat kształtuje się na świecie na poziomie około 4 miliardów, a pod 
koniec wieku ustabilizuje się na poziomie około 5,5 miliarda osób. Po trzecie wreszcie, należy oczekiwać znacznego wzrostu kategorii osób uznawanych obecnie za stare -zarówno w liczbach bezwzględnych, jak i w relacji do całej ludności (zob.Rysunek 2).
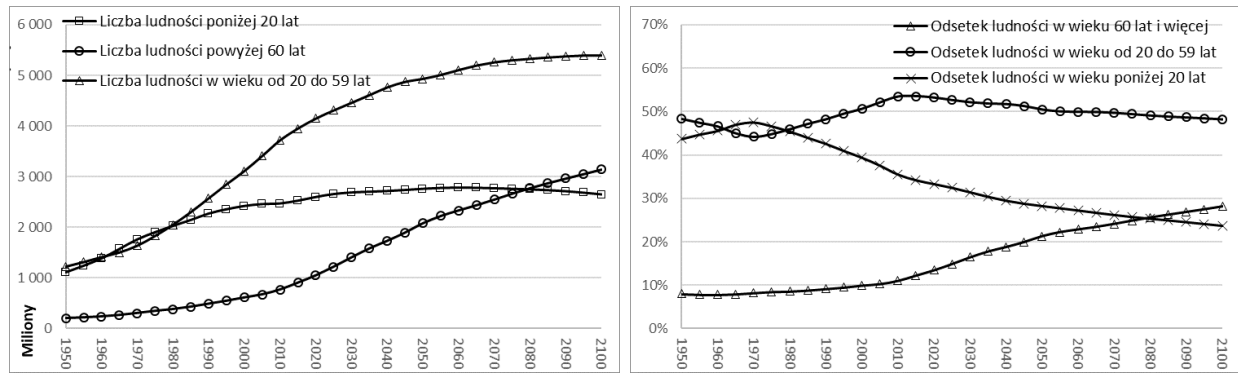

Rysunek 1. Ludność świata według wieku w wariancie średniej płodności

Źródło: opracowanie własne na podstawie projekcji ONZ (dane rzeczywiste do 2015 roku)

Jak już wspomniano, wraz ze wzrostem długowieczności oraz spadkiem płodności zwiększa się odsetek osób starszych wśród ogółu ludności świata. Jeszcze w 1950 roku na świecie żyło tylko około 200 milionów ludzi w wieku 60 lat i więcej, podczas gdy prawdopodobnie w 2020 roku ich liczba przekroczy po raz pierwszy miliard, co będzie stanowić 13,5\% populacji świata. Natomiast liczba osób w wieku 65 lat i więcej osiągnie po raz pierwszy miliard około 2030 roku. Przewiduje się, że pod koniec tego stulecia na świecie może żyć już ponad 3 miliardy osób w wieku 60 lat i więcej (około 28\% ludności świata) oraz 2,5 miliarda osób w wieku 65 lat i więcej (około 23\% ludności świata). Populacja osób w wieku sędziwym, tj. 80 lat i więcej, wynosiła w 1950 roku niespełna 15 milionów osób, a obecnie jest już dziesięć razy liczniejsza, choć nadal stanowi mniej niż 5\% ogółu ludności świata. Tymczasem pod koniec bieżącego stulecia liczba ludności w wieku 80 lat i więcej może wynieść ponad 900 milionów, co może stanowić nawet $8 \%$ ogółu populacji świata. Porównanie według płci pokazuje, że kobiety stanowią większość osób starszych - w 2015 roku na 100 kobiet w wieku 60 lat i więcej przypadało około 86 mężczyzn, natomiast w przyszłości ta dysproporcja ma maleć. W okresie ostatnich kilkudziesięciu lat odsetek osób, którym zostało 15 i mniej lat życia, utrzymywał się na świecie na stabilnym poziomie około 7\% ogółu ludności świata (zob. Rysunek 2). Jeszcze w 1950 roku na świecie żyło około 230 milionów osób, którym zostało 15 bądź mniej lat życia, a w 2015 roku było ich już 500 milionów. Odsetek osób, którym zostało 15 i mniej lat życia, nie zwiększał się w okresie ostatnich kilkudziesięciu lat, ponieważ wzrost długości życia, a co za tym idzie - wieku określającego początek okresu starości, rekompensował starzenie się struktury ludności według wieku. Jednak w przyszłości przewiduje się, iż frakcja osób, którym zostało 15 lat życia i mniej będzie rosnąć i pod koniec wieku może stanowić ponad 13\% ogółu ludności świata (około 1,5 miliarda osób - jest to jednak dwa razy mniej niż liczba osób w wieku 60 lat i więcej). 
Prognoza ONZ w wariancie wysokiej płodności zakłada, że współczynnik dzietności całkowitej w perspektywie najbliższych kilkudziesięciu lat nie spadnie poniżej poziomu gwarantującego zastępowalność pokoleń i pod koniec wieku wyniesie średnio około 2,45 dziecka przypadającego na kobietę w wieku rozrodczym. W tym wariancie liczba ludności świata ma rosnąć w całym horyzoncie prognozy i pod koniec wieku osiągnie wielkość 16 miliardów. Jednocześnie liczba osób młodych osiągnie pod koniec bieżącego stulecia wielkość 5 miliardów - blisko 30\% ogółu ludności świata i utrzyma się na poziomie wyższym niż liczba osób w wieku 60 lat i więcej (zob. Rysunek 3). Ponadto liczba osób w wieku od 20 do 59 lat będzie liczyć pod koniec wieku 8 miliardów osób, co będzie nadal stanowiło blisko połowę ludności świata. Natomiast liczba ludności w wieku 60 lat i więcej wzrośnie z około jednego miliarda obecnie do ponad 3,5 miliarda pod koniec wieku - będzie to stanowić wtedy około $22 \%$ ogółu ludności świata. Podobnie osoby w wieku 80 lat i więcej mają stanowić pod koniec wieku $6 \%$ ludności świata, podczas gdy aktualnie jest to około 2\%. Z kolei liczba osób, którym zostało 15 lat życia i mniej, ustabilizuje się od połowy wieku na poziomie około $10 \%$ populacji świata. Dlatego w konsekwencji dużego wzrostu zaludnienia świata proces demograficznego starzenia się ludności w ujęciu alternatywnym może zostać zatrzymany (zob. Rysunek 4).
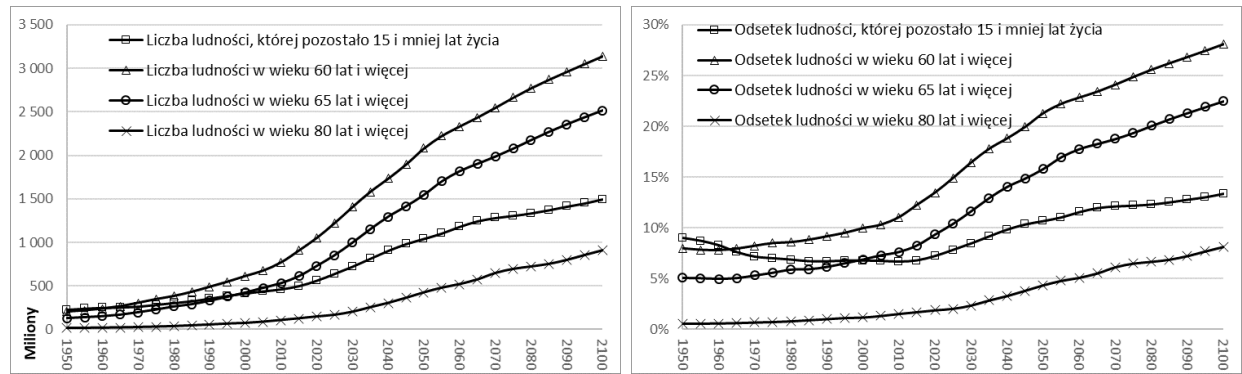

Rysunek 2. Ludność stara na świecie w wariancie średniej płodności Źródło: opracowanie własne na podstawie projekcji ONZ (dane rzeczywiste do 2015 roku)

W wariancie niskiej płodności prognozy sporządzonej przez ekspertów ONZ zakłada się, że współczynnik dzietności całkowitej spadnie poniżej progu gwarantującego poziom zastępowalności pokoleń już około 2025 roku i osiągnie pod koniec wieku wielkość niespełna 1,5 dziecka przypadającego na kobietę w wieku rozrodczym. Tak ekstremalnie niski poziom płodności, określany w literaturze jako lowest-low fertility rate, może mieć dramatyczne konsekwencje dla rozwoju liczebnego danej populacji - może spowodować zmniejszenie się o połowę jej liczebności w okresie poniżej 45 lat (Billari, Kohler, 2004; Kohler, Billari, Ortega; 2006). W świetle tej projekcji ludność świata osiągnie 9 miliardów osób w połowie wieku, a następnie zacznie się zmniejszać i wyniesie 7 miliardów pod koniec XXI wieku. Liczba osób w wieku 60 lat i więcej stanie się już w połowie wieku 
wyższa od liczby osób w wieku poniżej 20 lat i osiągnie wielkość 2,5 miliarda około 2075 roku - będzie to 35\% ludności (zob. Rysunek 5). Z kolei osoby młode mogą stanowić pod koniec wieku mniej niż $20 \%$ populacji świata. Natomiast liczba osób, którym zostało mniej niż 15 lat życia, będzie wynosić pod koniec wieku około 1,5 miliarda osób, co będzie stanowić aż 20\% ludności świata (zob. Rysunek 6).
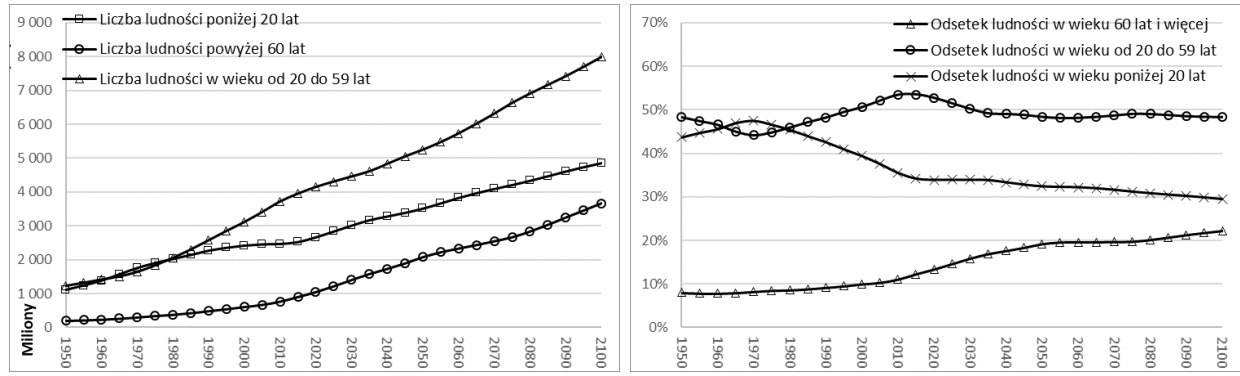

Rysunek 3. Ludność świata według wieku w wariancie wysokiej płodności

Źródło: opracowanie własne na podstawie projekcji ONZ (dane rzeczywiste do 2015 roku)
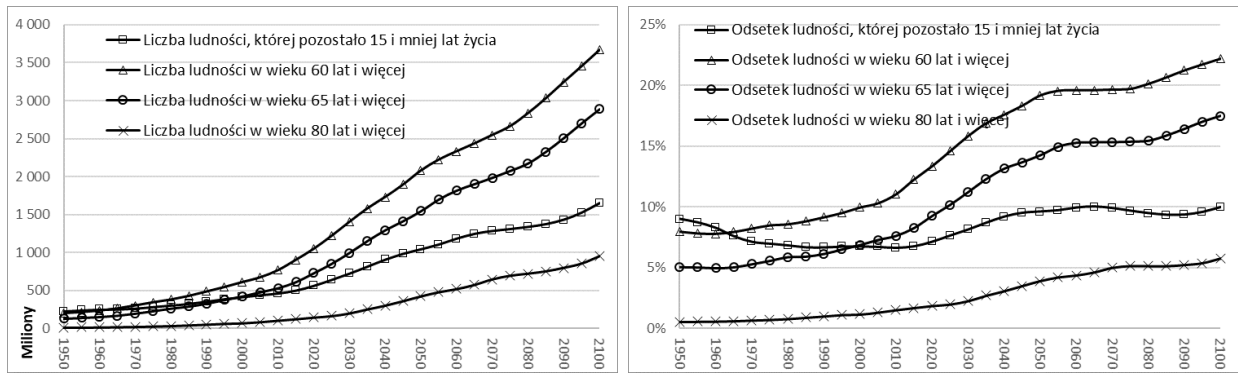

Rysunek 4. Ludność stara na świecie w wariancie wysokiej płodności Źródło: opracowanie własne na podstawie projekcji ONZ (dane rzeczywiste do 2015 roku)
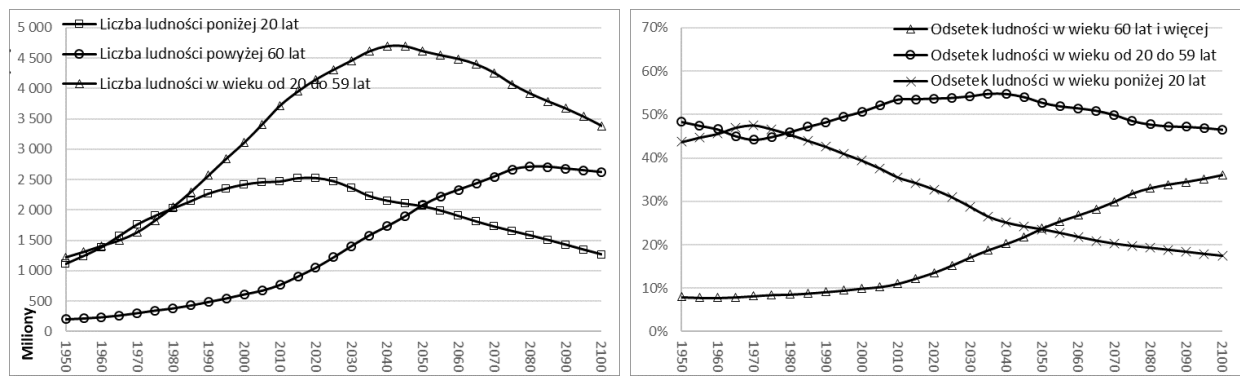

Rysunek 5. Ludność świata w wariancie niskiej płodności

Źródło: opracowanie własne na podstawie projekcji ONZ (dane rzeczywiste do 2015 roku) 


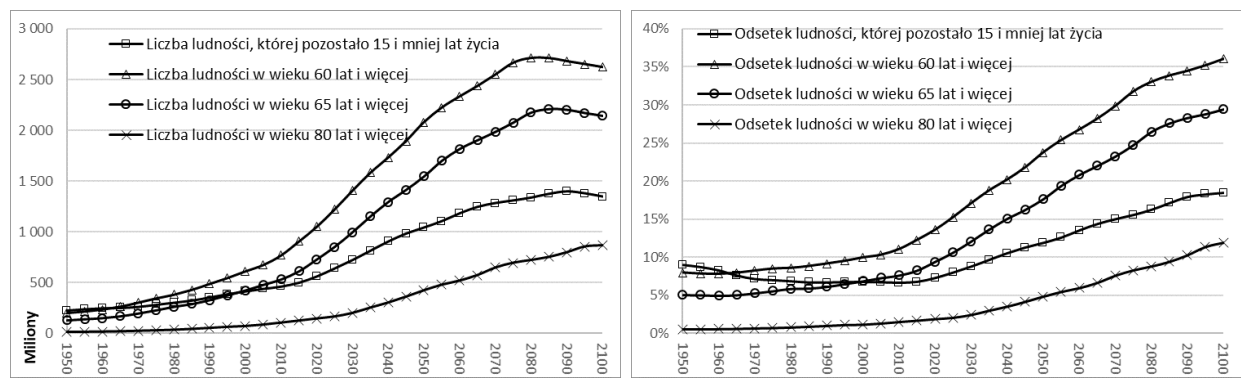

Rysunek 6. Ludność stara na świecie w wariancie niskiej płodności

Źródło: opracowanie własne na podstawie projekcji ONZ (dane rzeczywiste do 2015 roku)

\section{Zaawansowanie procesu starzenia się ludności świata według kontynentów w wariancie średniej płodności}

Przewiduje się, że dynamika przemian demograficznych zmieni całkowicie w najbliższych kilkudziesięciu latach strukturę zaludnienia świata według kontynentów. Co piąta osoba na świecie była w 1950 roku mieszkańcem Europy. Jednakże w kolejnych latach wyraźnie zmniejszyła się dzietność europejskich kobiet, dlatego Europa stanowi dziś $10 \%$ zaludnienia całego świata, a od około 2030 roku jej populacja zacznie się zmniejszać i pod koniec wieku stanowić będzie już tylko 6\% ludności świata. Liczba osób w wieku 60 lat i więcej stała się w Europie już w 2010 roku większa niż liczba osób w wieku 20 lat i mniej (zob. Rysunek 7). Ustabilizuje się ona w połowie wieku na poziomie około 250 milionów osób, co będzie stanowić ponad 35\% ogółu ludności kontynentu. Natomiast liczba osób, którym zostało mniej niż 15 lat życia, może się w przyszłości utrzymywać na stabilnym poziomie około 100 milionów osób - 15\% ludności kontynentu.

Przewiduje się, że populacja Azji będzie liczyć w połowie XXI wieku 5 miliardów mieszkańców, a następnie zacznie się zmniejszać. Ponadto w połowie obecnego stulecia liczba mieszkańców Azji w wieku 60 lat i więcej stanie się wyższa od liczby osób poniżej 20 lat (zob. Rysunek 8). Co piąty mieszkaniec Azji będzie miał pod koniec wieku mniej niż 20 lat, a co trzecia osoba będzie miała więcej niż 60 lat. Jednocześnie liczba osób, którym zostało 15 lat życia i mniej, będzie w perspektywie następnych kilkudziesięciu lat systematycznie rosnąć i pod koniec wieku może stanowić 17\% ogółu ludności Azji.

Ludność obszaru Ameryki Łacińskiej i Karaibów osiągnie około 2060 roku wielkość 800 milionów, a w kolejnych latach, podobnie jak w Europie czy Azji, wystąpi tam zjawisko depopulacji. Ponadto przewiduje się, że liczba osób w wieku 60 lat i więcej przewyższy w połowie stulecia liczbę osób w wieku 20 lat i mniej (zob. Rysunek 9). Dlatego tylko co piąty mieszkaniec Ameryki Łacińskiej będzie 
miał pod koniec wieku mniej niż 20 lat, a co trzeci będzie miał więcej niż 60 lat. Natomiast odsetek osób, którym zostało 15 lat życia i mniej, w perspektywie następnych kilkudziesięciu lat będzie się systematycznie zwiększać i osiągnie pod koniec wieku wielkość 17\% ogółu ludności.

Tabela 2. Projekcja ludności świata według kontynentów w wariancie średniej płodności (dane w mln)

\begin{tabular}{|c|c|c|c|c|c|c|c|}
\hline Wyszczególnienie & 1950 & 2000 & 2015 & 2030 & 2050 & 2080 & 2100 \\
\hline \multicolumn{8}{|c|}{ Afryka } \\
\hline Ludność ogółem & 229 & 818 & 1194 & 1704 & 2528 & 3799 & 4468 \\
\hline Ludność w wieku 0-19 lat & 118 & 438 & 613 & 816 & 1052 & 1258 & 1283 \\
\hline Ludność w wieku 20-59 lat & 99 & 337 & 517 & 781 & 1250 & 1976 & 2309 \\
\hline Ludność w wieku 60 lat i więcej & 12 & 42 & 64 & 107 & 226 & 565 & 876 \\
\hline Ludność, której zostało 15 lat życia i mniej & 17 & 40 & 51 & 75 & 136 & 298 & 452 \\
\hline \multicolumn{8}{|c|}{ Ameryka Północna } \\
\hline Ludność ogółem & 173 & 313 & 356 & 396 & 435 & 481 & 499 \\
\hline Ludność w wieku 0-19 lat & 59 & 89 & 91 & 94 & 99 & 105 & 106 \\
\hline Ludność w wieku 20-59 lat & 92 & 173 & 192 & 198 & 213 & 223 & 225 \\
\hline Ludność w wieku 60 lat i więcej & 21 & 51 & 74 & 104 & 123 & 153 & 168 \\
\hline Ludność, której zostało 15 lat życia i mniej & 16 & 30 & 32 & 47 & 57 & 67 & 71 \\
\hline \multicolumn{8}{|c|}{ Ameryka Lacińska i Karaiby } \\
\hline Ludność ogółem & 169 & 526 & 632 & 719 & 780 & 764 & 712 \\
\hline Ludność w wieku 0 - 19 lat & 85 & 222 & 218 & 204 & 180 & 150 & 135 \\
\hline Ludność w wieku 20 - 59 lat & 75 & 261 & 344 & 395 & 402 & 348 & 311 \\
\hline Ludność w wieku 60 lat i więcej & 9 & 43 & 71 & 120 & 198 & 266 & 266 \\
\hline Ludność, której zostało 15 i mniej lat życia & 9 & 25 & 33 & 51 & 83 & 120 & 121 \\
\hline \multicolumn{8}{|l|}{ 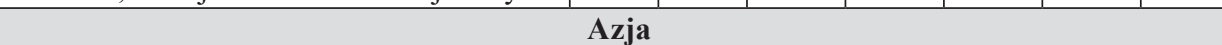 } \\
\hline Ludność ogółem & 1404 & 3730 & 4420 & 4947 & 5257 & 5070 & 4780 \\
\hline Ludność w wieku 0-19 lat & 651 & 1482 & 1436 & 1406 & 1271 & 1083 & 978 \\
\hline Ludność w wieku 20-59 lat & 661 & 1924 & 2470 & 2693 & 2713 & 2447 & 2228 \\
\hline Ludność w wieku 60 lat i więcej & 93 & 325 & 514 & 848 & 1273 & 1540 & 1575 \\
\hline Ludność, której zostało 15 lat życia i mniej & 137 & 230 & 300 & 457 & 672 & 788 & 797 \\
\hline \multicolumn{8}{|c|}{ Europa } \\
\hline Ludność ogółem & 549 & 727 & 741 & 740 & 716 & 668 & 653 \\
\hline Ludność w wieku 0-19 lat & 191 & 178 & 155 & 153 & 143 & 135 & 130 \\
\hline Ludność w wieku 20-59 lat & 293 & 401 & 410 & 368 & 326 & 302 & 290 \\
\hline Ludność w wieku 60 lat i więcej & 65 & 148 & 177 & 219 & 247 & 232 & 234 \\
\hline Ludność, której zostało 15 lat życia i mniej & 54 & 98 & 96 & 111 & 123 & 105 & 105 \\
\hline
\end{tabular}

Źródło: opracowanie własne na podstawie projekcji ONZ (dane rzeczywiste do 2015 roku)

Z kolei populacja Ameryki Północnej w perspektywie najbliższych kilkudziesięciu lat ma się systematycznie zwiększać i osiągnie pod koniec wieku 500 milionów. Jednakże tempo wzrostu zaludnienia tego kontynentu będzie słabnąć i pod koniec wieku wyniesie już mniej niż $0,2 \%$ rocznie. I choć dla Ameryki Północ- 
nej nie przewiduje się w perspektywie najbliższego stulecia wystąpienia zjawiska depopulacji, to jednak ludność w wieku 60 lat i więcej przewyższy już około 2025 roku ludność w wieku 20 lat i mniej (zob. Rysunek 10). Natomiast liczba osób w wieku 60 lat i więcej osiągnie pod koniec wieku prawie 170 milionów, co będzie stanowić blisko 35\% ogółu ludności kontynentu. Jednocześnie ludność, której zostało mniej niż 15 lat życia, ustabilizuje się po 2040 roku na poziomie podobnym jak w Europie, tj. około 15\% ogółu ludności Ameryki Północnej.
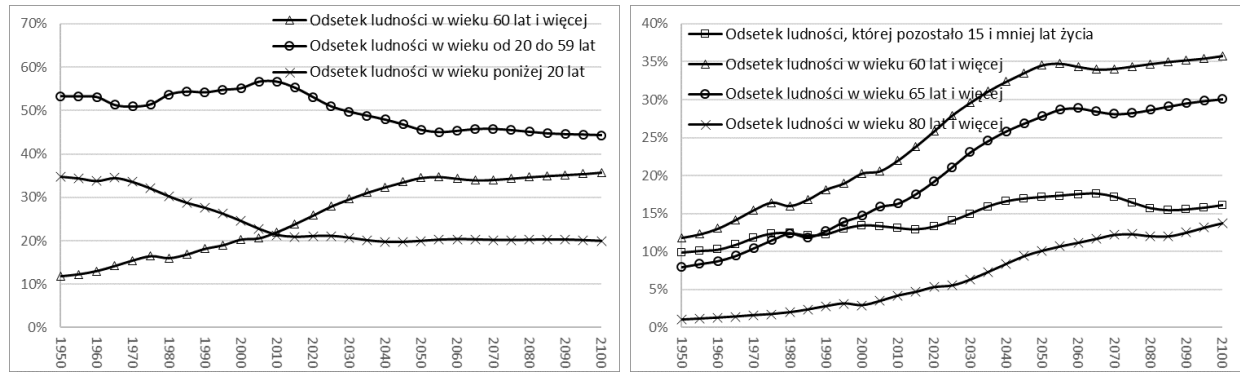

Rysunek 7. Ludność Europy w wariancie wysokiej płodności

Źródło: opracowanie własne na podstawie projekcji ONZ (dane rzeczywiste do 2015 roku)
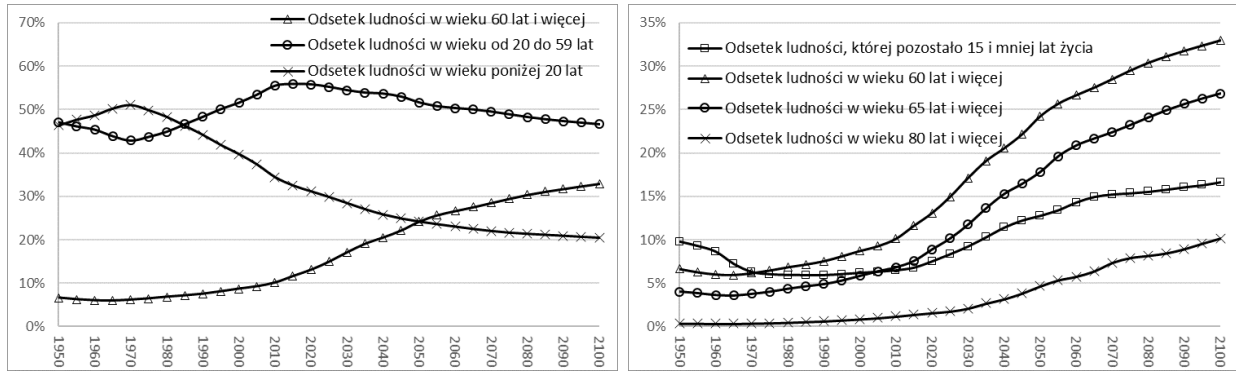

Rysunek 8. Ludność Azji w wariancie wysokiej płodności

Źródło: opracowanie własne na podstawie projekcji ONZ (dane rzeczywiste do 2015 roku)
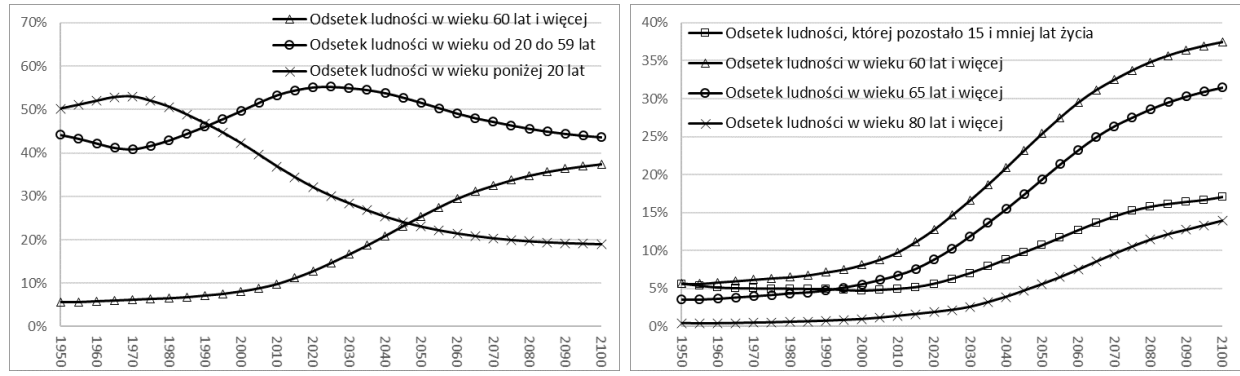

Rysunek 9. Ludność Ameryki Łacińskiej i Karaibów w wariancie wysokiej płodności

Źródło: opracowanie własne na podstawie projekcji ONZ (dane rzeczywiste do 2015 roku) 
Afryka będzie miejscem, w którym - w odróżnieniu od pozostałych kontynentów - wystąpią procesy dynamicznego wzrostu zaludnienia, określane w demografii mianem eksplozji demograficznej. Ludność Czarnego Kontynentu może wzrosnąć w najbardziej prawdopodobnym scenariuszu z około 1,2 miliarda obecnie nawet do 4,5 miliarda osób pod koniec wieku. Jednocześnie tempo rozwoju zaludnienia Afryki zmniejszy się z około $2,5 \%$ obecnie do $0,7 \%$ rocznie pod koniec bieżącego stulecia. Liczba osób w wieku od 20 do 59 lat wzrośnie z obecnego 0,5 miliarda do 2,3 miliarda osób pod koniec stulecia, co będzie stanowić 43\% ludności świata w wieku produkcyjnym. Z kolei liczba osób w wieku 20 lat i mniej może wzrosnąć w Afryce $\mathrm{z}$ obecnych 0,6 miliarda do blisko 1,3 miliarda osób pod koniec stulecia, co może stanowić prawie połowę wszystkich dzieci mieszkających na świecie. Równocześnie w Afryce przewiduje się też systematyczny wzrost liczby osób uznawanych za stare - liczba osób w wieku 60 lat i więcej zbliży się pod koniec bieżącego stulecia do miliarda, co będzie stanowiło około $20 \%$ ogółu ludności tego kontynentu, jednakże będzie to nawet o kilkanaście punktów procentowych mniej niż na innych kontynentach. Natomiast liczba osób, którym zostało mniej niż 15 lat życia, zacznie się zwiększać dopiero po 2030 roku i może osiągnąć pod koniec wieku wielkość około 0,5 miliarda osób - 10\% ogółu ludności kontynentu (zob. Rysunek 11).
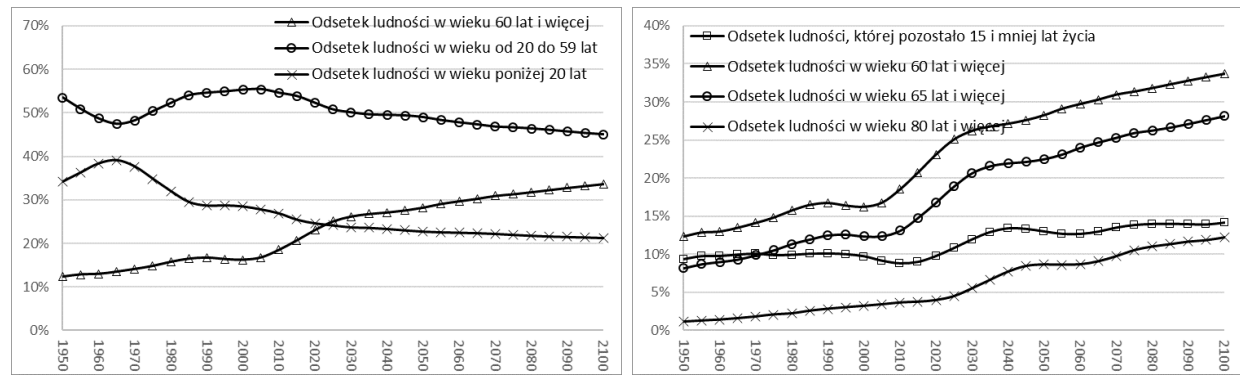

Rysunek 10. Ludność Ameryki Północnej w wariancie wysokiej płodności Źródło: opracowanie własne na podstawie projekcji ONZ (dane rzeczywiste do 2015 roku)
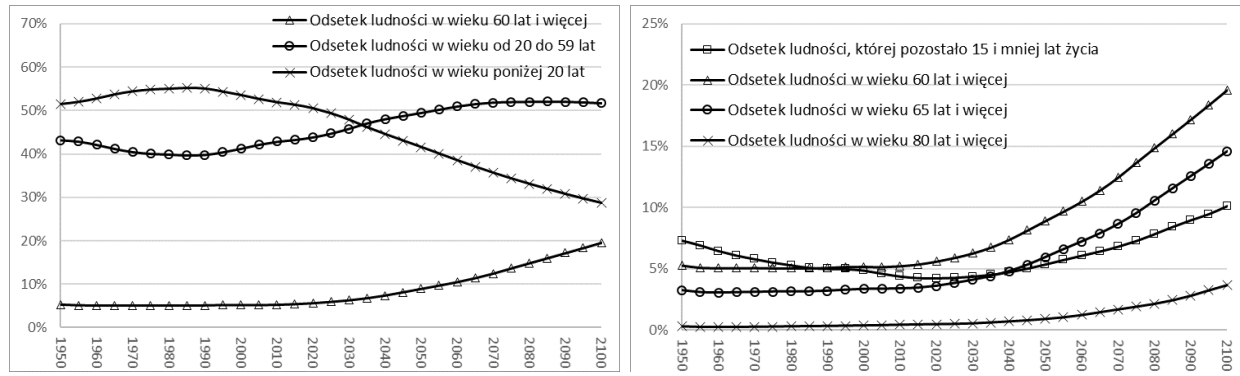

Rysunek 11. Ludność Afryki w wariancie wysokiej płodności Źródło: opracowanie własne na podstawie projekcji ONZ (dane rzeczywiste do 2015 roku) 
Reasumując, w wielu regionach świata wystąpi w najbliższych latach zjawisko depopulacji. Liczba dzieci w wielu miejscach stanie się niższa od liczby osób starszych. Ludność w wieku 60 lat i więcej może stanowić w wielu regionach świata ponad jedną trzecią ludności, a liczba osób, którym zostało mniej niż 15 lat życia, będzie zazwyczaj o mniej więcej połowę mniejsza od liczby osób w wieku 60 lat i więcej. Odsetek osób, którym zostało mniej niż 15 lat życia, ustabilizuje się w krajach najbardziej rozwiniętych na poziomie około 15\% ogółu ludności. Wśród wszystkich badanych kontynentów wyróżniać będzie się Afryka - ze względu na dynamiczny wzrost zaludnienia i jednocześnie dużo mniejszy stopień zaawansowania procesu starzenia się jej ludności. Dlatego w najbliższym czasie to nie problem wzrostu zaludnienia stanie się kluczowy w dyskursie demograficznym (oczywiście poza kontynentem afrykańskim), a raczej problemy związane ze starzeniem się ludności czy nierównowagą demograficzną między pokoleniem osób pracujących i osób starszych.

\section{Konsekwencje starzenia się ludności świata}

Aktualne projekcje rozwoju ludności świata wskazują, że proces globalnego starzenia demograficznego stanie się w najbliższych latach ogromnym wyzwaniem dla wielu społeczeństw, w tym dla całego międzynarodowego ładu ekonomicznego i społecznego. Dlatego ważne, aby odpowiednio wcześnie określić możliwe konsekwencje tego procesu i odpowiednio się do nich przygotować. W sferze ekonomicznej proces ten może spowodować zmniejszenie się ogólnego wzrostu gospodarczego świata, przede wszystkim w związku z tym, że mniej osób będzie mogło pracować, a więcej będzie pobierało emerytury i renty. Szansą na ograniczenie wpływu tego zjawiska może być poprawa stanu zdrowia osób starszych albo ustawowe wydłużenie wieku emerytalnego nawet do ponad 70 lat w najbardziej rozwiniętych gospodarczo krajach, co przełoży się na wzrost aktywności zawodowej tej grupy. Ponadto należy oczekiwać, że równolegle wzrośnie aktywność zawodowa innych grup, które dotychczas były relatywnie mało aktywne na rynku pracy - kobiet, mieszkańców wsi czy osób niepełnosprawnych. Dlatego koniecznym warunkiem ograniczenia wzrostu kosztów finansowania systemu emerytalnego czy systemu opieki nad osobami starszymi jest to, aby wydłużaniu się długości życia i w konsekwencji też długości okresu pracy towarzyszyła odpowiednia poprawa stanu zdrowia osób starszych, stąd konieczny będzie odpowiedni wzrost wydatków na służbę zdrowia. Ponadto niektóre z osób starszych nie będą w stanie sprostać wysokiemu wiekowi emerytalnemu, dlatego należy oczekiwać adekwatnego wzrostu kosztów rent, wcześniejszych emerytur, zwolnień i nieobecności w pracy czy kosztów opieki w domu. $Z$ tego względu nieuniknione stanie się w wielu krajach stworzenie kompleksowego systemu opieki nad osobami starszymi oraz nie- 
zdolnymi do pracy. Dodatkowo wzrost liczby osób w wieku sędziwym zwiększy zapotrzebowanie na specjalistyczne usługi medyczne i opiekuńcze. Jednocześnie, wraz z pojawianiem się kolejnych innowacji, może również wystąpić dalsza poprawa wydajności pracy, co da szansę na zneutralizowanie niekorzystnego wpływu procesu starzenia się ludności na globalny system ekonomiczny. Ponadto w sferze społecznej może wystąpić konflikt „młodzi - starzy” związany ze wzrostem obciążenia demograficznego, czego konsekwencją będą między innymi zmiany postaw wobec osób starszych. W sferze politycznej wzrost ilościowy elektoratu osób starszych spowoduje dominację w dyskursie politycznym potrzeb tej grupy wiekowej nad potrzebami innych grup społecznych. Jednocześnie należy oczekiwać wzmożenia procesów migracyjnych z krajów z dużą populacją osób młodych - w szczególności z państw afrykańskich - do państw zamożnych, o relatywnie starszej strukturze wiekowej ludności.

\section{Wnioski}

Przyjęcie stałego progu określającego początek starości (najczęściej jest to wiek 60 lub 65 lat) powoduje, że w społeczeństwie, w którym ludzie żyją dłużej, odsetek ludzi starych zawsze będzie się statystycznie zwiększać. Jednakże granica starości powinna zmieniać się wraz z wydłużaniem się ludzkiego życia, a w szczególności tej jego części, która przebiega w dobrym zdrowiu. Dlatego w alternatywnych ujęciach pomiaru zaawansowania procesu starzenia ludności poszukuje się bardziej adekwatnych definicji starości, które pozwolą uchwycić różnice między jakością długiego życia w różnych populacjach. Tradycyjny pomiar zaawansowania procesu starzenia się ludności na świecie wskazuje, że jest to proces nieuchronny oraz praktycznie nie do odwrócenia. W każdej ze wskazanych możliwych projekcji rozwoju ludności świata odsetek osób starszych rośnie. Z kolei alternatywny pomiar procesu starzenia się demograficznego wskazuje, że nieuchronność tego procesu nie jest już tak jednoznaczna. W projekcji wysokiej płodności odsetek osób, którym zostało 15 lat życia i mniej, stabilizuje się na poziomie około $10 \%$ ludności świata, a w wariancie średniej płodności na poziomie około 15\%. Wzrost długości przeciętnego dalszego trwania życia oraz poprawa jakości życia osób starszych spowodują, że w przyszłości granica określająca początek starości będzie się nieuchronnie zwiększać. Dlatego proces starzenia się od ,wierzchołka piramidy wieku ludności" może zostać zrekompensowany odpowiednim wzrostem wieku określającego początek starości. Natomiast zasadniczym problemem współczesnego świata będzie proces starzenia się od „dołu piramidy wieku ludności”, związany z niską płodnością kobiet na świecie, w wielu miejscach niegwarantującą nawet poziomu zastępowalności między pokoleniami. $Z$ tego powodu państwa o krytycznie niskiej płodności powinny już podejmować działania przeciwdziałające temu 
procesowi. Przykładowo: w Polsce wprowadzono program transferów pieniężnych do rodzin z dziećmi, zwany potocznie programem 500+. W Rosji państwo stara się zmotywować potencjalnych rodziców przez ekonomiczne zachęty dla matek, patriotyczne kluby i emocjonalną propagandę. W Japonii rząd próbuje zaspokajać popyt na usługi opiekuńcze dla osób starszych przez rozpowszechnianie różnych technologicznych udogodnień, takich jak na przykład zrobotyzowane koty, które służą jako zwierzęta domowe i jednocześnie monitorują parametry życiowe ich właścicieli. W Singapurze sloganem planowania rodziny było dotychczas „dwa wystarcza" - teraz jest to „troje dzieci lub więcej, jeśli możesz sobie na to pozwolić" (Daugherty, Kammeyer, 1995). Jednocześnie trzeba podkreślić, że różne państwa znajdują się na różnych etapach rozwoju demograficznego swojej populacji. Z jednej strony większość bogatych krajów leżących w Europie, Azji Wschodniej i Ameryce Północnej już w najbliższej przyszłości może się obawiać zjawiska depopulacji czy wysokiego stopnia zaawansowania procesu starzenia się swojej ludności. Z drugiej strony większość biedniejszych krajów świata, leżących w Afryce, na Bliskim Wschodzie, a także na południu i północnym wschodzie Azji, nadal kontynuuje szybki wzrost liczby ludności. Za większość notowanego w ostatnich latach wzrostu ludności świata odpowiada głównie czternaście dużych państw o niskich dochodach: Afganistan, Bangladesz, Demokratyczna Republika Konga, Etiopia, Indie, Indonezja, Irak, Kenia, Nigeria, Pakistan, Filipiny, Sudan, Tanzania i Uganda (Goldstone, 2012: 26-27). W przyszłości według prognoz za większość wzrostu liczby ludności świata odpowiadać będą państwa leżące w Afryce.

\section{Bibliografia}

Abramowska-Kmon A. (2011), O nowych miarach zaawansowania procesu starzenia się ludności, „Studia Demograficzne”, nr 1(159), s. 3-22.

Billari F. C., Kohler H.P. (2004), Patterns of low and very low fertility in Europe, „Population Studies", nr. 58(2), s. 161-176.

Daugherty H.G., Kammeyer K.C.W. (1995), An Introduction to Population, Guilford Press, New York.

Goldstone J.A. (2012), A Theory of Political Demography: Human and Institutional Reproduction, [w:] J.A. Goldstone, E.P. Kaufmann, M.D. Toft (red.), Political Demography: How Population Changes Are Reshaping International Security and National Politics, Oxford University Press, New York, s. 26-27.

Kohler H.P., Billari F.C., Ortega J.A. (2006), Low fertility in Europe: Causes, implications and policy options, [w:] F. R. Harris (red.), The Baby Bust: Who will do the Work? Who Will Pay the Taxes?, Rowman \& Littlefield Publishers, Lanham-Boulder-New York-Toronto-Oxford, s. $48-109$.

Lutz W., Sanderson W., Scherbov S. (2008), The coming acceleration of global population ageing, „Nature”, nr. 451, s. 716-719.

Murkowski R. (2018), Metody pomiaru zaawansowania procesu starzenia się ludności, „Humanities and Social Sciences", nr. 25(3), s. 213-229, http://doi.org/10.7862/rz.2018.hss.49 
Myrskylä M., Kohler H.P., Billari F.C. (2009), Advances in development reverse fertility declines, „Nature”, nr. 460(7256), s. 741-743.

Sanderson W., Scherbov S. (2005a), A new perspective on population aging, „Demographic Research", nr. 16, s. 27-58.

Sanderson W., Scherbov S. (2005b), Average remaining lifetimes can increase as human populations age, „Nature”, nr. 435(7043), s. 811-813.

Sanderson W., Scherbov S. (2008), Rethinking Age and Aging, „Population Bulletin”, nr. 63.

Sanderson W., Scherbov S. (2010), Remeasuring aging, „Science”, nr. 329, s. 1287-1288.

United Nations, Department of Economic and Social Affairs, Population Division (2017), World Population Prospects: The 2017 Revision, DVD Edition.

\title{
The State and Perspectives of the World Population Aging Process
}

\begin{abstract}
The aging of the population is the process of increasing the proportion of older people in the population, which is the result of two long-term demographic trends: a decrease in fertility and an increase in life expectancy. For the correct measurement of the advancement of this process, it is extremely important what age we consider the beginning of the old age. In the traditional approach older people are most often considered to be people over 60 or 65 years of age. In the alternative approach the beginning of the old age can be considered the age which the expected life expectancy is exactly 15 years. In many parts of the world, the phenomenon of depopulation may appear in the coming years, and the number of children will be lower than the number of older people. In the future, older people will be in nearly one third of their entire population in many regions. However, the percentage of people who have 15 or fewer years to live will stabilize in the future at about $15 \%$ of the total population in the most developed countries. Therefore, the beginning of the old age will grow in the future up to 70 years and more in the most developed countries.
\end{abstract}

Keywords: aging of the population, alternative measures of aging of the population, demographic forecasts, senility, beginning of the old age

JEL: $J 11, J 14, J 13$

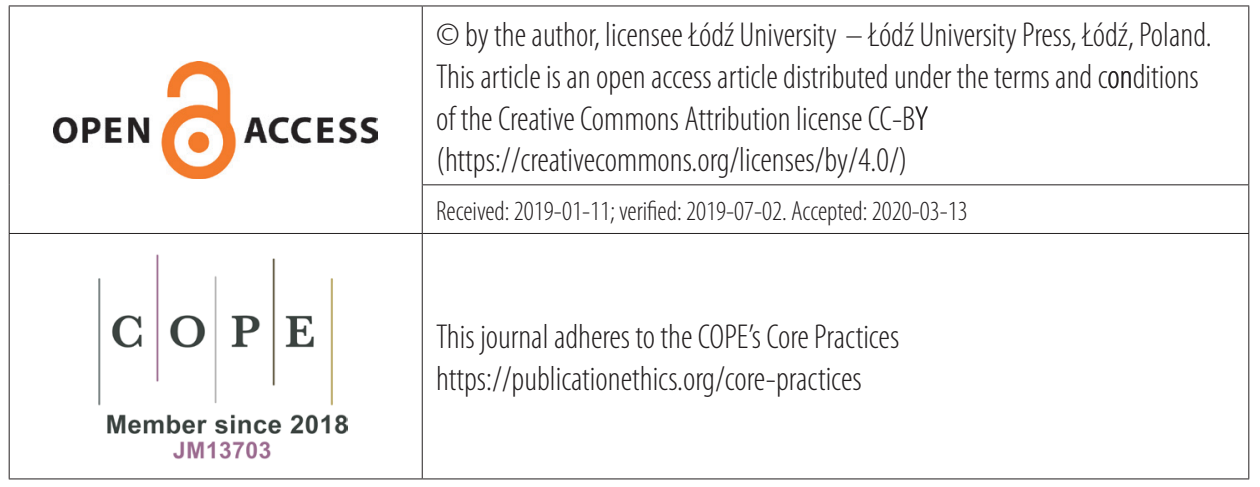

